\title{
First Record of Holothurian Symbiotic Crab Asthenognathus inaequipes (Decapoda: Brachyura: Varunidae) from Korea
}

\author{
Seok Hyun Lee, Kyu Hyun Lee and Hyun Sook Ko* \\ Department of Biological Sciences, Silla University, Busan 617-736, Korea
}

\begin{abstract}
A hole dwelling holothurian symbiotic crab was collected in the low tidal mark in Namhae Island. The crab was identified as Asthenognathus inaequipes Stimpson, 1858 and found to be new to Korean waters. The species was briefly illustrated and described.
\end{abstract}

Keywords: Varunidae, holothurian symbiotic crab, Asthenognathus inaequipes, Korea

\section{INTRODUCTION}

The genus Asthenognathus Stimpson, 1858 was formerly retained in the family Pinnotheridae (see Sakai, 1976). Recently, $\mathrm{Ng}$ et al. (2008) placed it in the family Varunidae because it was markedly different from other pinnotherid genera in characteristics of the thoracic sternum, the penial structure, the abdomen, the gonopods, and the pereopods. At present, the genus includes four species: Asthenognathus inaequipes Stimpson, 1858, A. atlanticus Monod, 1933, A. hexagonum Rathbun, and A. gallardoi Serène and Soh, 1976 (see $\mathrm{Ng}$ et al., 2008). Among them, a male of A. inaequipes was collected for the first time in a hole of holothurian Protankyra bidentata (Woodward and Barrett, 1858) and found to be new to Korean waters. Therefore, a brief description and illustration of the specimen is provided.

Drawings were made with the aid of camera lucida. The abbreviations "cl" and "cw" refer to carapace length from the tip of rostrum to the posterior dorsal margin of the carapace and to the width of the carapace measured at the widest part, respectively. Specimen was preserved in $95 \%$ ethanol. The classification follows that of $\mathrm{Ng}$ et al. (2008). Material examined in this study is deposited in collection of Silla University, Busan.

\section{SYSTEMATIC ACCOUNTS}

Superfamily Grapsoidea MacLeay, 1838

Family Varunidae H. Milne Edwards, 1853

\footnotetext{
*To whom correspondence should be addressed

Tel: 82-51-999-5473, Fax: 82-51-999-5176

E-mail: hsko@silla.ac.kr
}

${ }^{1 *}$ Subfamily Asthenognathinae Stimpson, 1858

2*Genus Asthenognathus Stimpson, 1858

${ }^{3 *}$ Asthenognathus inaequipes Stimpson, 1858 (Figs. 1, 2) Asthenognathus inaequipes Stimpson, 1858, p. 107; Sakai, 1935 , p. 206 , text-fig. 110,1939 , p. 601 , fig. 86 ; Sakai, 1976, p. 588, fig. 324a, pl. 203; Takeda and Konishi, 1991, p. 36, fig. 3; Ng et al., 2008. P. 226 (list).

Material examined. $1 \mathrm{o}^{7}(\mathrm{cl} 6.8 \mathrm{~mm}, \mathrm{cw} 10.8 \mathrm{~mm})$, Namhae Island, 2 Jun. 2007 (S.H. Lee).

Description. Carapace (Fig. 1A) roundly hexagonal, 1.59 times as broad as long; dorsal surface flat, almost naked; urogastric region with groove; intestinal region depressed; front slightly concave in middle; anterolateral margin entire, pubescent; posterior margin broader than width of frontalorbital margin. Third maxilliped (Fig. 1B) narrowly gaping; ischium proximally broad, longer than merus; suture between ischium and merus transverse; merus subquadrate, slightly longer than broad, dactylus of palp cylindrical, jointed at tip of propodus. Chelipeds (Fig. 1C) symmetrical, stout; merus and carpus furnished with long setae along dorsal surface; palm stout, inner surface smooth; movable finger of male cheliped with 3 broad teeth on inner margin proximally, distal part smooth. Ambulatory legs (Fig. 1D-G) covered with tomentum on outer surface, furnished with long setae on anterior and posterior margins; ambulatory leg 2 the longest, ambulatory leg 3 slightly shorter than ambulatory leg 2, ambulatory leg 4 reduced in size. Ambulatory legs 2 and 3 each with merus twice as long as broad; propodus approximately as long as dactylus, both slightly shorter than carpus. Male abdomen (Fig. 1H) pagoda-shaped; somites distinctly separated; somite 6 trapezoid, much broader than long, lateral margins convex; telson round, longer than broad. Gonopod (Fig.

$1 *$ 납작등게아과 (신칭), ${ }^{2 *}$ 납작등게속(신칭), ${ }^{3 *}$ 납작등게 (신칭) 

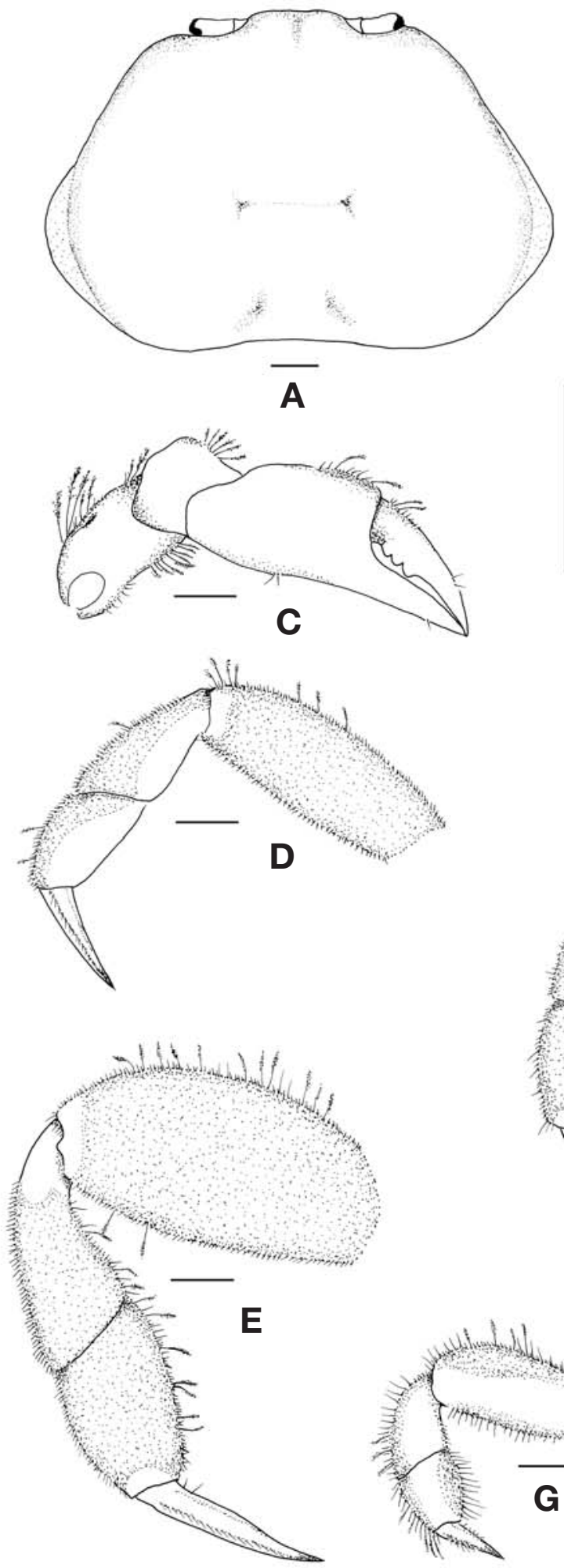

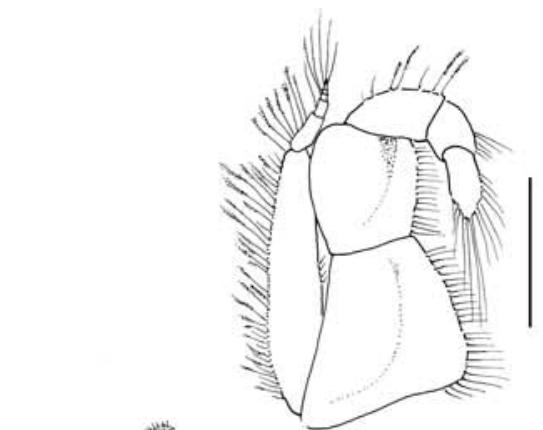

B
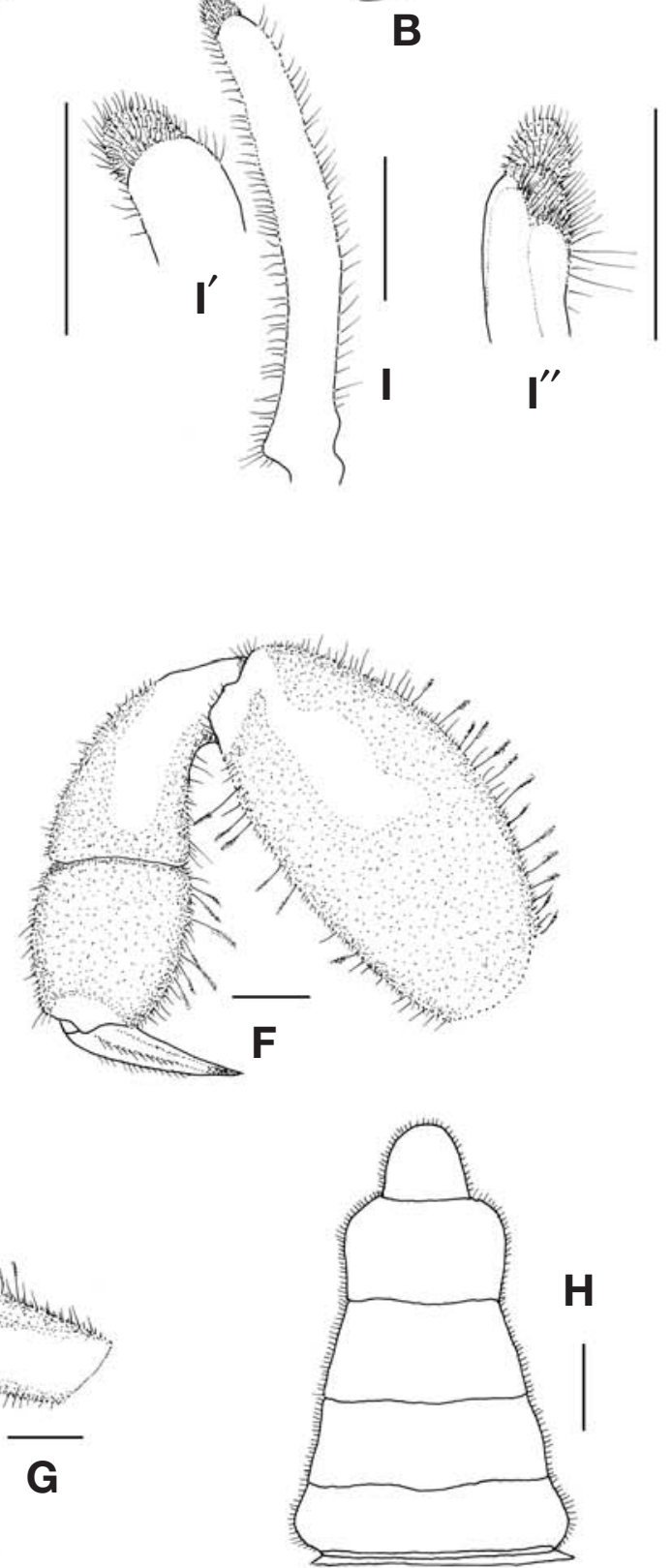

Fig. 1. Asthenognathus inaequipes Stimpson, 1858, male (cw $10.8 \mathrm{~mm}$ ). A, dorsal view of carapace; $B$, third maxilliped, ventral view; C, left cheliped, dorsal view; D-G, first to fourth ambulatory legs; $\mathrm{H}$, abdomen and telson, ventral view; $\mathrm{I}$, gonopod and enlargement of distal part (I', ventral; I", dorsal). Scale bars=1 mm (A-I"). 


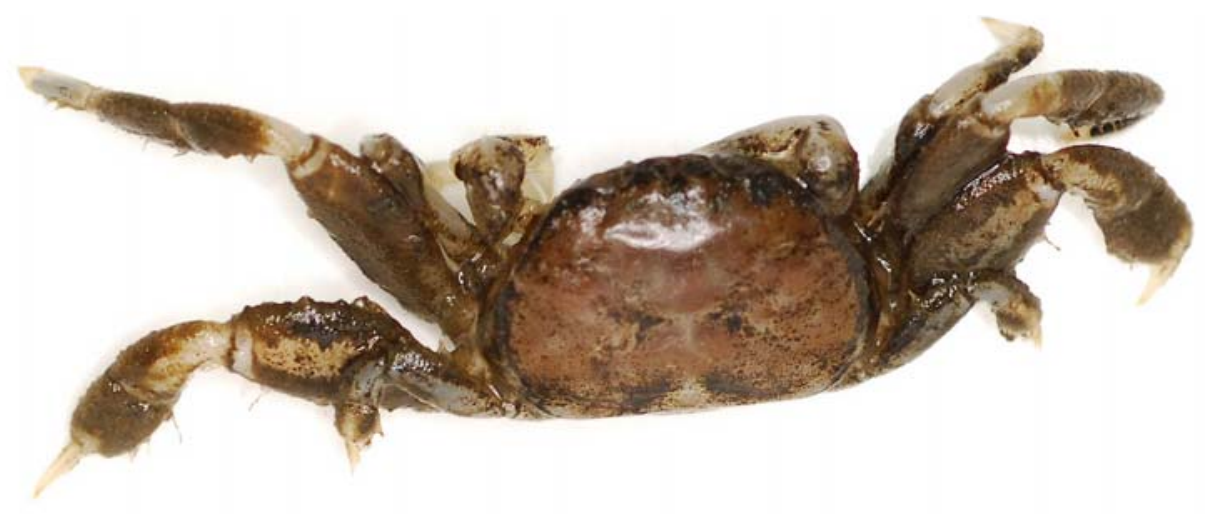

Fig. 2. Asthenognathus inaequipes Stimpson, 1858, male (cw $10.8 \mathrm{~mm}$ ), digital camera image of live animal.

$\left.1 \mathrm{I}-\mathrm{I}^{\prime \prime}\right)$ slightly bent outwardly; furnished with long setae on lateral margins; distal portion roundly truncated, covered with long setae on apex.

Color in life. Generally brown, distal margin of meri, proximal margin of carpi and dactli white.

Remarks. The specimen agrees closely with the description of Sakai (1939) except in the number of the tooth on the inner margin of the movable finger in the male cheliped. It had an obtuse tooth in his description and a figure of Takeda and Konishi (1991) and two small teeth was described in the key of the Indo-Pacific species of Asthenognathus by Yang and Tang (2008). However, the present male specimen has three teeth, therefore, the number of tooth seems to be variable according to the specimens.

Habitat. Muddy bottom in intertidal region.

Distribution. Japan, East China Sea (Sakai, 2004), and now Korea.

\section{ACKNOWLEDGEMENTS}

This work was derived from the "Flora and Fauna of Korea" project supported by on the National Institute of Biological Resources, the Ministry of Environment, Korea.

\section{REFERENCES}

Ng, P.K.L., D. Guinot and P.J.F. Davie, 2008. Systema Brachyurorum: Part 1. An annotated checklist of extant brachyuran crabs of the world. Raffles Bull. Zool., 17: 1-286.

Sakai, K., 2004. Crabs of Japan. World Biodiversity Database CD-ROM series.

Sakai, T., 1935. Crabs of Japan. Sanseido, Tokyo, pp. 1-239, figs. 1-122.

Sakai, T., 1939. Studies on the crabs of Japan. IV. Brachygnatha, Brachyrhyncha, Yokendo Co., Tokyo, pp. 365-741, figs. 1129, pls. 42-111, table 1.

Sakai, T., 1976. Crabs of Japan and the adjacent seas. Kodansha Ltd, pp. 1-773, pls. 1-251.

Stimpson, W., 1858. Prodromus descriptionis animalium evertebratorum, quae in Expeditione ad Oceanum Pacificum Septentrionalem, a Republica Federata missa, Cadwaladaro Ringgold et Johanne Rodgers Ducibus, observavit et descripsit. Pars V. Crustacea Ocypodoidea. Proc. Acad. Nat. Sci. Philadelphia, 10: 93-110.

Takeda, M. and K. Konishi, 1991. Pinnotherid crabs from Otsuchi Bay, Iwate Prefecture, northeastern Japan. Otsuchi Mar. Res. Cent. Rep., 17: 29-39.

Yang, S.L. and B.P. Tang, 2008. Description of the male of Asthenognathus hexagonum Rathbun, 1909 (Decapoda, Pinnotheridae). Crustaceana, 81: 595-600.

Received October 4, 2010 Accepted November 12, 2010 